\title{
Problematika Moralitas Anak pada Masa Pandemi Covid-19 Perspektif Immanuel Kant: Studi Kasus Di Kampung Cikaso Desa Sukamukti Kecamatan Cisompet Kabupaten Garut
}

\author{
Yeni Wahyuni \\ Jurusan Aqidah dan Filsafat Islam \\ Fakultas Ushuluddin UIN Sunan Gunung Djati Bandung, Indonesia \\ yeniwahyuni9910@gmail.com
}

\begin{abstract}
The purpose of this study was to analyze the problems of children's morality during the Covid-19 pandemic from the perspective of Immanuel Kant. This research is a qualitative research using descriptive methods of phenomenology and moral philosophy for a case study in Cikaso Village, Sukamukti Village, Cisompet District, Garut Regency. The findings in this research show that the impact of the Covid-19 pandemic does not only affect the health sector, but the education sector is also affected where character education and morality of children receive less attention from the policy makers. As for the point of view of Immanuel Kant's moral philosophy, explaining that morality is divided into two parts, namely hypothetical imperatives and categorical imperatives. This study concludes that the morality of children in Cikaso Village is mostly included in the hypothetical imperative. This study recommends for further and in-depth research on studies of morality, especially in the perspective of Immanuel Kant.
\end{abstract}

Keywords: Categorical imperative, Hypothetical imperative, Morality, Pandemic.

\begin{abstract}
Abstrak
Tujuan penelitian ini adalah untuk menganalisis problematika moralitas anak pada masa pandemi Covid-19 perspektif Immanuel Kant. Penelitian ini merupakan penelitian kualitatif dengan menggunakan metode deskriptif fenomenologi dan filsafat moral untuk studi kasus di Kampung Cikaso Desa Sukamukti Kecamatan Cisompet Kabupaten Garut. Penemuan dalam riset ini menunjukan bahwa dampak pandemi Covid-19 tidak hanya berimbas pada bidang kesehatan saja, namun bidang pendidikan juga terkena imbasnya dimana pendidikan karakter dan moralitas
\end{abstract}


anak itu kurang mendapatkan perhatian dari pihak pemegang kebijakan. Adapun sudut pandang dari filsafat moral Immanuel Kant, menjelaskan bahwa moralitas itu dibagi kedalam dua bagain, yaitu imperatif hipotesis dan imperatif kategoris. Penelitian ini menyimpulkan bahwa moralitas anak di Kampung Cikaso itu sebagian besar termasuk kedalam imperatif hipotesis. Penelitian ini merekomendasikan untuk adanya penelitian lebih lanjut dan mendalam mengenai kajian-kajian tentang moralitas terutama dalam perspektif Immanuel Kant.

Kata kunci: Imperatif hipotesis, Imperatif kategoris, Moralitas, Pandemi.

\section{Pendahuluan}

Wabah Covid-19 merupakan wabah penyakit yang berasal dari kota Wuhan provinsi Hubei. Awalnya penyakit ini diberi nama 2019 Novel Coronavirus (2019-nCoV) kemudian WHO (World health Organization) mengumumkan nama baru pada tanggal 11 Februari 2020 yaitu Corona Virus Dieses (Covid-19). Wabah penyakit ini disebabkan oleh virus Severe Acute Respiratory Syndrome Coronavirus-2 (SARS-CoV-2). Hingga pada 12 Maret 2020, WHO mengumumkan Covid-19 sebagai pandemi. Pada tanggal 29 Maret 2020, terdapat 634.835 kasus dan 33.106 jumlah kematian di seluruh dunia. Sementara di Indonesia sudah ditetapkan 1.528 kasus dengan positif Covid-19 dan 136 kasus kematian (Susilo , 2020).

Wabah Covid-19 merupakan salah satu wabah pandemik yang telah melanda hampir seluruh dunia, termasuk Indonesia. Dengan adanya wabah penyakit ini, tentu saja hal tersebut sangat berdampak pada beberapa sektor yang ada di dunia. Tidak hanya pada bidang kesehatan, namun bidang perekonomian, sosial, pendidikan bahkan pariwisata pun ikut terkena imbasnya. Pemerintah mengeluarkan Surat Edaran pada tanggal 18 Maret 2020 mengenai penanggulangan wabah Corona sehingga kegiatan diluar ruangan untuk sementara waktu ditutup dulu (Dewi \& $\mathrm{dkk}, 2020$ ).

Akibat dari adanya wabah pandemi ini banyak negara yang memutuskan untuk menutup sekolah, akademi, dan bahkan universitas. Semua orang menjaga jarak, menjauhi kerumunan, dan bahkan jarang sekali berpergian. Semua aktifitas mereka lakukan di dalam ruangan. Sistem pembelajaran daring di satu sisi memanglah merupakan solusi di masa pandemi ini. Namun di sisi lain dampak burukpun tak kalah hebatnya mengintai. Meskipun secara formal pendidikan bisa 
tersampaikan pada murid, namun pendidikan moral peserta didik selama pandemik ini sepertinya sedikit terabaikan.

Pemberlakuan sistem belajar jarak jauh atau daring ini mengakibatkan terbatasnya ruang gerak dan interaksi antara guru dan murid. Selain itu, penggunaan perangkat digital atau smartphone sebagai media pembelajaran dalam waktu yang cukup lama tidak menjamin bisa membuat anak terbebas dari paparan konten negatif. Demikian pula maraknya perilaku amoral dan kurangnya sopan santun anak terhadap orang yang lebih dewasa mengakibatkan etika anak menjadi merosot.

Lamanya sistem pembelajaran online menjadikan suatu alasan bagi mereka untuk menghabiskan waktu dan berlama-lama dengan media digital. Selain itu, banyak dari mereka yang meminta bantuan orang tua untuk menyelesaikan tugasnya. Sedangkan orang tua yang tinggal diperkampungan kebanyakan masih gagap teknologi terhadap media sosial bahkan tak jarang dari mereka yang tidak mempunyai smartphone.

Sejauh yang diamati krisis moralitas anak dan remaja pun terjadi di Kampung Cikaso Desa Sukamukti, Kecamatan Cisompet Kabupaten Garut. Masyarakat Kampung Cikaso sebagian besar berprofesi sebagai petani, dan pedagang. Kampung Cikaso ini terletak di RW 04 yang terdiri dari 4 RT. RT 01 terletak di Kampung Cikaso, RT 02 di Kampung Cipamulihan, RT 03 di Kampung Jambudipa, dan RT 04 di Kampung Legok ganas. Jika dilihat dari aspek keagamaan, warga masyarakat sepenuhnya menganut ajaran Islam (Desa Sukamukti , 2019).

Menurut Ketua Karang Taruna sebenarnya pandemi Covid-19 itu membawa dampak positif dan tak sedikit pula memberikan dampak negatif. Dampak positifnya ketika pembelajaran dilakukan secara daring, orang tua bisa memantau anak secara langsung dan tau kapasitas anak sampai dimana. Namun, sisi negatifnya anak menjadi lebih banyak menggunakan media sosial, bahkan media dijadikan alasan untuk anak bisa menolak perintah dari orang tua. Misalnya ketika orangtua menyuruh anaknya untuk membelikan sesuatu ke warung, lalu anak itu menolak dengan alasan sedang belajar online atau sedang mengerjakan tugas.

"Menurut saya hal itu merupakan hal negatif karena cara belajar online itu sering dijadikan alasan untuk bermalas-malasan. Anak-anak lebih sering nongkrong sampai larut malam dan keluyuran. Jam main anak biasanya jam 9 malam pun sudah pada pulang, sedangkan di masa pandemi ini mereka lebih suka begadang sampai larut malam bahkan sampai menginap dengan alasan bahwa besok siangnya bebas tak pergi ke sekolah. Bahasa-bahasa yang diucapkan oleh anak kepada orang yang lebih dewasa pun menjadi kurang sopan mungkin dikarenakan lebih sering main di luar. Bayangkan saja jika pandemi terus berlanjut dan sikap anak masih seperti itu, maka tindakan tersebut akan menjadi sebuah kebiasaan buruk 
dan akan menjadi sesuatu yang melekat pada diri anak terhadap orangtua" (Saepul, 2020).

Anak-anak yang ada di Kampung Cikaso ini sebagian besar baru masuk Sekolah Dasar (SD), Sekolan Menengah Atas (SMA), dan paling banyak yang baru masuk Sekolah Menengah Pertama (SMP). Penulis mencoba mengamati anak-anak yang baru mau masuk ke SMP. Mengapa demikian, karena pada masa ini anak-anak baru memulai peralihan dari masa kanak-kanak menuju ke masa remaja dan rasa keingintauan dan penasarannya pun cukup tinggi. Banyaknya orangtua yang berprofesi sebagai petani, sehingga tak jarang dari mereka yang lebih banyak menghabiskan waktu di sawah dan ladang. Hal tersebutlah yang menjadikan kurangnya perhatian orang tua terhadap anaknya, sehingga anakpun lebih babas dan lebih rentan terhadap paparan krisis moralitas (Oamidin, 2020).

Melihat fenomena yang terjadi di kampung Cikaso penulis tertarik untuk mendalaminya dengan menggunakan sudut pandang filsafat etika Immanuel Kant. Kant merupakan filusuf asal Jerman (1724-1804). Dalam bukunya yang berjudul "Simpul Pemikiran Etika Immanuel Kant Implementasinya dalam Pembelajaran" Kant mengemukakan bahwa "dalil pertama moralitas adalah memiliki nilai moral sejati, dan perbuatan harus dikerjakan sesuai kewajiban."

Ada beberapa tulisan yang berkaitan dengan pembahasan tentang moralitas anak di masa pandemi ini. Salah satunya yaitu artikel dengan judul "Work Frome Home (WFH) dan Pembentukan Kecerdasan Moral Anak Di Masa Pandemi Covid-19" (Permatasari , 2020). Artikel ini membahas tentang dampak positif dan negatif yang diperoleh ketika proses WFH di masa pandemi ini direalisasikan. Dampak positif yang diperoleh ketika WFH dilaksanakan di rumah yaitu waktu orang tua untuk berkumpul dan berinteraksi dengan anaknya semakin banyak dan semakin besar pula kemungkinan orang tua untuk bisa mengarahkan anaknya, sehingga terbentuklah moralitas yang baik terhadap anak tersebut. Namun sebaliknya, dampak negatif yang timbul akibat dari adanya WFH di masa pandemi ini, yaitu tak jarang dari orangtua yang merasa dirinya terbebani karena mendapatkan pekerjaan yang double (Permatasari , 2020). Tulisan yang selanjutnya yaitu terdapat pada artikel yang berjudul "Solusi Bias Kognitif, Kesenjangan Digital dan Moralitas Di Era Pandemi Covid-19" (Permana \& dkk, 2021). Artikel ini memaparkan tentang beberapa solusi yang bisa kita gunakan dalam menghadapi berbagai problema di masa pandemi Covid-19 ini. Fenomena masyarakat yang kurang peduli akan kondisi pandemi yang semakin merajalela, dikarenakan rendahnya kemampuan literasi sehingga terjadilah bias kognitif. Kesenjangan digital pun kerap terjadi di beberapa pedesaan dan krisis moralitas terhadap 
peserta didik pun semakin meningkat (Permana \& dkk, 2021). Dan yang terakhir yaitu terdapat pada artikel yang berjudul "Problematika Pembelajaran Jarak Jauh pada Masa Pandemi Covid-19: Studi Kasus Di SMP IT Nurul Fajri-Cikarang Barat-Bekasi" (Basar, 2021). Artikel ini memaparkan tentang beberapa problema yang terjadi ketika proses pembelajaran jarak jauh ini direalisasikan. Ada bebrapa faktor yang mempengarui sehingga proses Pembelajaran Jarak Jauh (PJJ) ini belum bisa dikatakan sebagai kondisi belajar yang ideal (Basar, 2021).

Beberapa studi di atas memaparkan tentang problematika yang muncul di masa pandemi Covid-19. Kesamaan antara penelitian-penelitian terdahulu dengan penelitian yang akan penulis lakukan, yaitu terletak pada objek dan waktu yang dilakukan, yaitu pada masa pandemi Covid19. Namun perbedaannya terletak pada sudut pandang yang dijadikan pisau analisis. Dalam artikel ini penulis akan mengulas tentang "Problematika Moralitas Anak pada Masa Pandemi Covid-19 Perspektif Immanuel Kant" yang mana dalam penelitian ini penulis menggunakan perspektif filsafat etika dari Immanuel Kant yang belum dipakai pada penelitian-penelitian sebelumnya.

Sistem etika pada umumnya menekankan pada hasil dari suatu perbuatan. Namun, lain halnya dengan Immanuel Kant yang tidak hanya mengukur baik buruknya suatu perbuatan dilihat dari hasilnya saja. Immanuel Kant lebih menekankan pada apa maksud dari si pelaku melakukan tindakan tersebut. Oleh karena itu, sistem ini tidak menyoroti tujuan yang dipilih terhadap perbuatan atau keputusannya, melainkan wajib atau tidaknya perbuatan itu untuk dilakukan. Sehingga teori Kant tersebut dinamai dengan Deontologi. Asal katanya yaitu Deon yang berarti apa yang harus dilakukan, yaitu kewajiban. Teori Kant macam ini kerap sekali disebut dengan Deontologisme yang keras. Mengapa demikian, karena menurutnya "Tujuan akhir manusia adalah pemenuhan atas kewajiban" (Widyawati, 2016). Aliran etika Kant ini dinamakan juga sebagai Kantian Etics (Effendi, 2020).

Menurut Kant, filsafat moral atau etika murni itu bersifat a priori. Yang mana etika macam ini hanya menggulati berbagai macam perumusan dan pembenaran atas berbagai prinsip moral. Hingga munculah berbagai istilah seperti "wajib dan kewajiban, benar atau salah, dan baik atau buruk." Immanuel Kant menamai etika a priori ini dengan Metaphysik der sitten (Metafisiska Kesusilaan). Namun, etika selain bersifat a priori, juga bersifat aposteriori atau empiris. Etika macam ini oleh Immanuel Kant disebut dengan Praktische Anthropologie (Antropologi Praktis) (Widyawati, 2016).

Poespoprodjo mengatakan bahwa "moralitas adalah kualitas manusia yang terkandung dalam suatu perbuatan dan menunjukan benar atau salah, dan baik atau buruknya suatu perbuatan." Suatu perbuatan bisa dikatakan bernilai moral apabila tindakan tersebut atas dasar keinginanya 
sendiri dan adanya kesadaran akan kewajiban. Bukan atas dasar adanya paksaan dari luar, sehingga ia merasa takut atau karena adanya reward dan keberhasilan yang diinginkan. Sikap moral yang serupa dengan ini, oleh Immanuel Kant dinamai dengan moralitas (Widyawati, 2016).

Selanjutnya, Kant membagi moralitas kedalam dua bagian, yaitu moralitas heteronom dan moralitas otonom. Moralitas heteronom adalah moralitas yang dilakukan bukan atas dasar pada kehendak diri sendiri, melainkan adanya dorongan dari pihak luar. Contohnya yaitu ketika seorang anak yang rajin salat atas dasar takut pada guru ngaji atau orang tua. Dia rajin ibadah karena takut dihukum ketika ditanya. Hal semacam itu menurut Kant dapat menghancurkan nilai moral. Menurutnya "Tidak ada yang lebih mengerikan daripada tindakan seseorang yang harus takluk kepada kehendak pihak lain." Bagi Kant "The heteronomy of the will as the source of all spurious principles of morality." Yaitu, heteronomy kehendak adalah sebagai sumber segala moralitas palsu (Widyawati, 2016).

Lain halnya dengan moralitas heteronom, moralitas otonom justru merupakan kebalikan dari definisi moralitas heteronom itu sendiri. Bagi moralitas otonom, orang dewasa normal dapat memerintahkan dirinya dalam berbagai macam masalah moral dan secara efektif kita dapat mengendalikan diri kita. Menurut Kant "The autonomy of the will as the supreme principle of morality." Yaitu, otonomi kehendak adalah sebagai prinsip moral tertinggi (Widyawati, 2016).

Moral bukan merupakan monopoli agama atau bangsa tertentu. Menurut Kant ada aturan kesusilaan umum yang berlaku untuk setiap individu. Karena letak moral sendiri berada di dalam diri manusia, oleh karena itu tidak dapat dipengaruhi oleh apa saja yang berada di luarnya. Adanya perasaan wajib untuk bertindak, sehingga menimbulkan kehendak baik yang seolah-olah memerintah, namun tidak memaksa. Perintah wajib yang timbul dari kehendak baik ini oleh Kant dinamakan Imperatif Kategoris. Sedangkan jika suatu perbuatan dikatakan baik, dilihat dari hasil yang diperoleh itu dinamakan Imperatif Hipotesis (Asdi, 1995).

Tujuan penelitian ini untuk menjawab beberapa permasalahan yang dijadikan pokok pembahasan yaitu: 1) Bagaimana moralitas anak pada masa pandemi Covid-19 di Kampung Cikaso; dan 2) Bagaimana tinjauan Immanuel Kant terhadap moralitas anak di Kampung Cikaso. Atas dasar itulah, dalam batasan-batasan tertentu teori filsafat moral dari perspektif ini akan dijadikan acuan dalam penelitian agar dapat melihatnya secara utuh, mendalam, objektif dan komprehensif.

\section{Metode Penelitian}

Metode yang digunakan dalam penelitian ini yaitu metode kualitatif sehingga menghasilkan data deskriptif, baik berupa perkataan maupun tulisan dari orang-orang dan perilaku yang dapat diamati (Tanzeh, 2011). 
Alasan penulis mengambil jenis metodologi penelitian ini yaitu agar dapat mengamati, mendeskripsikan, dan memaparkan data hasil penelitian di lapangan (field research). Penelitian deskriftif kualitatif adalah suatu rancangan penelitian yang menggambarkan data penelitian secara objektif. Yaitu dengan cara pengumpulan data, pengolahan data, dan penyajian data secara objektif (Basar, 2021).

Pengumpulan data dilakukan melalui tiga tahapan, yaitu dengan cara observasi, wawancara, lalu dokumentasi. Observasi merupakan proses awal saat kita akan memulai penelitian. Proses ini dilakukan secara sistematis mengenai fenomena alam dan gejala-gejala sosial melalui pengamatan dan pencatatan. Proses selanjutnya yaitu wawancara. Wawancara dilakukan untuk memperkuat dan memperdalam data yang telah diperoleh. Bagian terakhir yaitu dokumentasi. Dokumentasi adalah catatan peristiwa yang sudah berlalu, baik itu berupa catatan, tulisan, gambar, atau karya-karya monumental dari seseorang. Teknik dokumentasi ini merupakan pelengkap dari proses-proses sebelumnya, yaitu teknik observasi dan wawancara (Sugiyono, 2014).

Sumber data yang digunakan yaitu menggunakan sumber primer dan sekunder. Data primer yaitu data yang diperoleh langsung dari sumber pertama. Dalam penelitian ini yaitu anak, orang tua, dan masyarakat di Kampung Cikaso. Sedangkan data sekunder adalah sebuah data pendukung atau tambahan yang diperoleh dari jurnal-jurnal, artikel, skripsi, buku, atau karya ilmiah lainnya yang berkaitan dengan penelitian yang dilakukan (Azwar, 1999). Dalam penelitian ini, peneliti hanya menggambarkan dan mendeskripsikan tentang problematika moralitas anak pada masa pandemi Covid-19 di Kampung Cikaso dengan menggunakan pisau analisis dari teori Immanuel Kant.

Selanjutnya, untuk penentuan pemilihan informan dalam penelitian ini menggunakan teknik purvosive sampling (sampling bertujuan) yang mana teknik ini digunakan untuk menentukan sample melalui pertimbangan-pertimbangan tertentu. Hasil pertimbangan tersebut dilakukan untuk menentukan informan yang dianggap paling mengetahui tentang apa yang akan dibutukan dalam penelitian, atau seseorang tersebut mempunyai peran atau posisi yang sangat berpengaruh sehingga dapat mempermudah peneliti dalam pengambilan data atau informasi dari objek atau situasi yang akan diteliti (Sugiyono, 2014).

Adapun waktu dan tempat dilaksanakannya penelitian ini yaitu di Kampung Cikaso Desa Sukamukti Kecamatan Cisompet Kabupaten Garut dan dilaksanakan mulai dari awal bulan Desember 2020 sampai awal bulan Juni 2021. Penelitian ini dilakukan pada 5 orang informan yang meliputi : Ohim/Oamidin (Ketua Rw./Petugas sekolah), Saepul (Tokoh Masyarakat/Ketua Karang Taruna), Ustadz Dede Abdul Fatah (Tokoh Agama), Rosita (Orang Tua), dan Sultan (Anak). Keenam informan 
tersebut dipilih berdasarkan teknik purposive sampling karena dianggap mampu mendeskripsikan tentang problematika moralitas anak yang terjadi di Kampung Cikaso.

\section{Hasil dan Pembahasan}

Kampung Cikaso merupakan Suatu Perkampungan yang terletak di Desa Sukamukti Kecamatan Cisompet Kabupaten Garut. Luas wiayah Desa Sukamukti yaitu $4.083 \mathrm{M}$, yang terdiri dari 3 dusun, 9 RW dan 31 RT. Letak demografis atau batas wilayah Desa Sukamukti yaitu, sebelah Utara berbatasan dengan Desa Cisompet, sebelah Timur berbatasan dengan Desa Cihaurkuning, sebelah Selatan berbatasan dengan Desa Sukanagara, sebelah Barat berbatasan dengan Desa Panyindangan. Mayoritas penduduknya bermata pencaharian sebagai petani, buruh, pedagang, dan hanya beberapa yang berprofesi sebagai PNS (Pegawai Negeri Sipil). Masyarakat Kampung Cikaso sepenuhnya beragama Islam dan bersuku Sunda. Banyaknya masyarakat yang berprofesi sebagai petani dan kurangnya kepercayaan mereka mengenai adanya virus Corona (Covid-19) menjadikan tidak terganggunya aktivitas mereka di ladang dan sawahnya. Hal tersebutlah yang menjadi salah satu penyebab turunnya moralitas anak di masa pandemi ini. Orang tua yang lebih banyak menghabiskan waktu di ladang dan sawahnya, dan anak yang membutuhkan bantuan serta pengawasan selama pembelajaran jarak jauh ini menjadi salah satu problem yang ditimbulkan selama masa pandemi.

Pada masa Covid-19 ini, banyak sekali problematika yang dialami oleh masyarakat. Tidak hanya yang berkaitan dengan kesehatan saja, namun kondisi pendidikan dan moralitas anak pun nampaknya sedikit terganggu. Diberlakukannya sistem pembelajaran jarak jauh (daring) mengharuskan pengajar dan murid untuk tetap melaksanakan pembelajaran walaupun tidak saling bertatapan. Hal tersebut sesuai dengan keputusan Menteri Pendidikan dan Kebudayaan Republik Indonesia terkait dengan Surat Edaran No. 4 Tahun 2020 tentang Pelaksanaan Kebijakan Pendidikan dalam Masa Darurat Penyebaran Covid-19 (Basar, 2021).

Sistem pembelajaran daring di satu sisi memanglah merupakan solusi di masa pandemi ini. Namun di sisi lain dampak buruk pun tak kalah hebatnya mengintai. Meskipun secara formal pendidikan bisa tersampaikan pada murid, namun pendidikan moral peserta didik selama pandemi ini sepertinya sedikit terabaikan. Pemberlakuan sistem belajar jarak jauh atau daring ini mengakibatkan terbatasnya ruang gerak dan interaksi antara guru dan murid. Selain itu, penggunaan perangkat digital atau smartphone sebagai media pembelajaran dalam waktu yang cukup lama tidak menjamin bisa membuat anak terbebas dari paparan konten negatif. Demikian pula maraknya perilaku amoral dan kurangnya sopan 
santun anak terhadap orang yang lebih dewasa mengakibatkan etika anak menjadi merosot. Bertitik tolak pada hasil riset di lapangan, problematika moralitas anak di masa pandemi yang dilakukan di Kampung Cikaso ini, akan diulas sebagai berikut:

\section{Moralitas Anak pada Masa Pandemi Covid-19 Di Kampung Cikaso}

Secara historis, masyarakat Kampung Cikaso adalah golongan masyarakat kelas menengah ke bawah. Hal tersebut bisa kita lihat dari sistem mata pencaharian masyarakat Kampung Cikaso yang sebagian besar hanya berpropesi sebagai petani. Banyaknya waktu yang dihabiskan oleh orang tua di sawah dan ladangnya menjadikan waktu pertemuan anak dan orang tua menjadi tersita. Kurangnya pantauan orang tua terhadap anak, dapat mempengaruhi tingkat moralitas pada anak. Menurut Agustin dan Tri Wahyuningsih, merosotnya nilai moral yang terjadi dikalangan pelajar atau anak muda menimbulkan sikap keragu-raguan pada diri orang tua untuk menentukan nilai moral yang baik, yang dapat dijadikan patokan (Pasaribu, 2018).

Pendidikan dan pembinaan nilai moral pada anak memanglah sangat penting. Hal tersebut bertujuan agar anak dapat memiliki rasa tanggung jawab atas setiap tindakan yang dilakukannya. Diberlakukannya sistem pembelajaran jarak jauh (daring) memanglah merupakan suatu solusi yang dianggap tepat dalam menghadapi situasi dan kondisi saat ini. Namun nampaknya kita lupa bahwa, pendidikan karakter itu tidak bisa jika hanya dilaksanakan lewat maya. Pada masa darurat Covid-19 ini, anak-anak lebih banyak menghabiskan waktu di rumah dan bergulat dengan gadget. Hal tersebut sesuai dengan apa yang dikatakana oleh Saepul berikut:

“Dampak negatif dari pembelajaran daring tentu saja banyak, namun salah satunya dan yang paling utama yaitu, anak menjadi lebih banyak menggunakan media dan bahkan media dijadikan suatu alasan bagi anak untuk bermalas-malasan. Misalnya ketika orang tua meminta bantuan "Neng cing pang meserkeun anu..." lalu anak menolak dengan alasan sedang belajar online. Maka orang tua pun akan kalah dan tidak bisa apa-apa, karena orang tua sudah pasti memprioritaskan pendidikan anaknya dan tidak mau mengganggu mood anaknya sehigga malas untuk belajar lagi" (Saepul, 2021).

Pernyataan tersebut dikuatkan pula oleh jawaban dari Ustadz yang mengajar ngaji di Kampung Cikaso, yaitu Ustadz Dede Abdul Fatah. Berikut pernyataanya:

"Selain karena faktor pandemi, moralitas anak pun dipengaruhi oleh HP (Handphone). Hampir 100\% anak-anak usia di atas 6 tahun itu 
disibukkan dengan HP, sehingga ngaji pun menjadi terbengkalai dan sekolah pun barangkali menjadi tidak serius. Kebanyakan anak ketika diminta bantuan oleh orang tua, terlebih ketika mereka sedang main games, memang sangatlah susah, bahkan susah sekali. Belum tiga kali mah orang tuanya memanggil, mereka belum juga menjawab untuk mentaati perintah orang tuanya. Dan bahkan ketika ada temannya lewat lalu menyapanya, sedangkan si anak sedang enjoy main HP terkadang anak itupun nyaris tidak menjawabnya dengan baik. Karena ya itu, mereka sangat keasikan dengan games. Nah itulah faktor-faktor yang menurut saya sangat dominan dalam mempengaruhi moraitas anak" (Fatah, 2021).

Dari uraian di atas dapat disimpulkan bahwa problematika moralitas anak di Kampung Cikaso pada masa pandemi ini memanglah sangat dipengaruhi oleh berbagai macam faktor.

\section{Faktor-faktor Moralitas Anak pada Masa Pandemi Covid-19}

Pendidikan merupakan suatu unsur penting dalam pembentukan karakter anak. Tanpa pendidikan suatu bangsa atau masyarakat akan mengalami kesulitan untuk maju sehingga menjadi suatu bangsa atau masyarakat yang kurang beradab. Menurut Pratiwi, jika sistem pendidikan dalam suatu bangsa berkualitas maka akan menghasilkan sumber daya manusia yang berkualitas pula. Karena bangsa yang maju dapat dilihat dari pendidikan yang ada di dalamnya (Arifah, 2020).

Namun sistem pendidikan dalam kondisi pandemi Covid-19 saat ini, tentu saja sangatlah berbeda seperti saat bertatap muka. Banyak hal yang perlu dibahas mengenai pendidikan di masa pandemi ini. Mulai dari kurikulum pembelajaran, media yang akan digunakan, metode pembelajaran, begitupun dengan kesiapan antara tenaga pendidik dan anak didiknya. Dari beberapa hal yang menjadi faktor yang mempengaruhi moralitas anak, di antaranya:

\section{a) Pantauan Orang Tua}

Peran orang tua dalam membimbing perkembangan moralitas anaknya memanglah sangat penting. Pengaruh lingkungan keluarga merupakan faktor utama yang dapat menentukan moralitas anak agar tidak terbawa arus global. Segala bentuk, isi, dan cara didikan orang tua akan mempengaruhi tumbuh dan berkembangnya kepribadian seorang anak. Oleh karena itu, di situlah peran penting orang tua untuk dapat mengarahkan anaknya agar bisa berinteraksi secara baik dengan sesama mahluk. Baik itu interaksi antar sesama manusia, maupun lingkungan alam sekitarnya (Pasaribu, 2018). Sebagaimana yang disampaikan oleh Ustadz Dede Abdul Fatah berikut: 
"Berbicara mengenai sopan santun seorang anak, itu sangat dipengaruhi oleh didikan dari orang tua. Anak yang binaan dari orang tuanya baik, maka akhlak dan sopan santunya pun baik. Tapi anak yang kurang didikan dari orang tuanya maka sopan santunnya pun berkurang dan nyaris tidak ada. Namun pada saat ini, memang didikan orang tua sangat lemah mengenai akhlak dan tatakrama untuk anak-anaknya" (Fatah, 2021).

Masyarakat yang hidup di Kampung Cikaso sebagian besar berpropesi sebagai petani, pedagang, dan beberapa orang yang merantau keluar kota. Ada beberapa anak yang tinggal bersama kakek neneknya, saudaranya, dan bahkan ada yang hanya tinggal dengan salah satu dari orang tuanya, karena ibu atau bapaknya sudah meninggal.

Beberapa faktor tersebut dapat mempengaruhi moralitas anak. Salah satunya ketika orang tua disibukkan dengan pekerjaannya, maka menjadikan perhatian dan kasih sayang terhadap anaknya pun berkurang. Di samping itu komunikasi yang dijalin antara anak dan orang tua pun dapat mempengaruhi terhadap baik buruknya moralitas anak. Seperti apa yang disampaikan oleh Rosita berikut ini:

"Semakin ke sini, semakin buruk moral yang dicerminkan oleh anak terhadap orang tua. Contohnya anak saya, ketika disuruh pun kadang suka membangkang dan kadang suka tidak digubris sama sekali. Nada ucapannya pun kadang suka melebihi nada yang disampaikan orang tua. Entah karena saya jarang di rumah sehingga kurang dalam mendidik anak, dan waktu untuk berkomunikasi pun berkurang" (Rosita, 2021).

Orang tua harus bisa mendidik anak secara tegas, karena seorang anak tidak bisa diperlakukan dengan didikan keras dan toriter, jika mereka diperlakukan dengan keras, maka yang terjadi anak akan semakin memberontak. Hal tersebut sesuai dengan apa yang disampaikan oleh Rosita, sebagai berikut:

"Anak laki-laki itu susah untuk diatur. Karena semakin keras didikan orang tua, maka akan semakin memberontak lah dia. Saya hanya takut kalau anak saya ketika dimarahi malah kabur dan tidak pulang-pulang. Kalau sudah begitu kan nanti akan menjadi beban pikiran, makanya saya selalu membiarkan apapun aktifitas anak, asalkan dia ada di rumah walaupun kesehariannya disibukan dengan games dan gadget " (Rosita, 2021).

Dengan demikian, kita dapat mengambil kesimpulan bahwa peran orang tua dalam memantau anak-anaknya memanglah sangat berpengaruh 
terhadap moralitas yang akan dicerminkan oleh anak itu sendiri. Anak yang baik didikannya, makan akan mencerminkan moralitas yang baik, begitupun sebaliknya.

\section{b) Lingkungan}

Lingkungan merupakan salah satu faktor yang sangat mempengaruhi moralitas anak. Mengapa demikian, karena ketika anak melakukan interaksi dengan lingkungan sosialnya, maka akan terjadi hubungan yang saling mempengaruhi dan dipengaruhi satu sama lain. Menurut Ahmad, teman sebaya merupakan salah satu peran penting yang dapat mempengaruhi perkembangan anak di lingkungan sosialnya. Ketika anak berteman dengan orang baik, maka ia dapat menjalin hubungan dengan baik, begitupun sebaliknya (Utami ,2018). Kurangnya perhatian dari orang tua, menjadikan anak mencari kesibukan di dunia luar dan terbawa oleh pengaruh negatif dari lingkungan teman sebayanya. Dengan demikian, moralitas anakpun akan rusak dan menimbulkan berbagai macam kenakalan remaja. Begitupun dengan kasus yang terjadi di Kampung Cikaso, berikut ulasan dari Saepul:

“Ada beberapa peningkatan di luar prediksi mengenai moralitas anak di masa pandemi ini. Hal-hal yang tak seharusnya diakukan oleh anak seusia mereka, tapi karena anak lebih banyak bermain di luar, tidak sekolah dan tak ada kegiatan maka mereka lakukan. Dampak negatif yang ditimbulkannya yaitu seperti merokok, bergadang, main keluyuran, atau bahkan mabuk-mabukan. Anak-anak yang pulang mengaji lalu ikut nongkrong, kalau sekolah biasanya jam 9 malam pun sudah pada pulang. Namun di masa pandemi ini anak-anak nongkrong bisa sampai jam 11, 12, atau bahkan menginap, karena alasannya besok santai dan tidak sekolah. Anak yang tidak bisa jaga pergaulan ketika di luar, terkadang banyak dari mereka yang terjerumus ke dalam dunia minum-minuman keras. Anakanak SMP pasti ketika main di luar, main di jalanan yang bebas, dan kurangnya perhatian dari lingkungan sekitar, mungkin saja bisa melakukan hal tersebut. Namun di lingkungan Kampung Cikaso ini, saya kira tidak terjadi hal-hal yang demikian, paling 2 dari 10 orang anak ada yang main di luaran, tapi tidak melakukan hal tersebut. Namun yaa, wallahu'alam karena saya belum pernah melihat secara langsung, secara garis besar peningkatan aktivitas yang di luar kewajaran pastilah ada (Saepul, 2020).

Melihat fenomena tersebut, dapat kita pahami bahwa problematika moralitas anak yang terjadi di Kampung Cikaso ini memanglah sangat krisis. Dampak negatif yang ditimbulkan dari lingkungan sekitar pun sangat berpengaruh terhadap perilaku yang dicerminkan oleh anak. 


\section{c) Sistem Pembelajaran}

Menurut Bilfaqih dan Qomarudin, pembelajaran jarak jauh (daring) adalah sistem pembelajaran yang menggunakan model interaktif berbasis internet dan Learning Management System (LMS). Pembelajaran daring merupakan program kelas belajar dalam jaringan yang dapat menjangkau masyarakat secara luas, dengan menggabungkan teknologi elektronika dan teknologi berbasis internet. Pendekatan model daring memiliki karakteristik contructivism, social contructivism, community of learners yang inklusif, interaktif, kemandirian, aksebilitas, dan pengayaan pembelajaran berbasis komputer (Asmuni, 2020).

Pembelajaran daring merupakan sistem pembelajaran yang tidak dapat terelakkan lagi bagi setiap instansi pendidikan. Di tengah pandemi Covid-19 ini, pembelajaran daring merupakan sistem pembelajaran yang dianggap akan dapat menjadi solusi agar sistem pendidikan bisa terus berlangsung. Karena sistem pembelajaran daring ini sangat identik dengan pemanfaatan fitur teknologi berbasis internet, yang sangat bergantung pada ketersediaan teknologi informasi. Maka, tak jarang dari sejumlah peserta didik yang tinggal di wilayah pedesaan mereka mengalami kesulitan untuk mengakses internet. Hal tersebut terjadi karena gangguan signal yang tidak memadai dan pengetahuan orang tua yang masih gaptek terhadap gadget itu sendiri. Pernyataan tersebut sesuai dengan apa yang dikatakan oleh Ustadz Dede Abdul Fatah berikut:

"Sistem pembelajaran daring untuk saat ini memang bisa dikatakan belum tepat, bahkan jauuuh, sekali dari kata tepat. Mengapa demikian, karena anak hanya melaksanakan tugas saja tanpa mau untuk memahaminya. Bahkan dalam keseharian pun ketika mereka belajar lewat daring dan ada pelajaran-pelajaran yang sifatnya mendidik seperti pendidikan moral atau akhlak mereka nampaknya tidak pernah mempraktekannya, karena memang tidak ada yang membimbingnya dan hanya sekedar menulis teori-teorinya saja. Setelah beres, ya mereka kembali untuk bermain lagi" (Fatah, 2021).

Proses PJJ memanglah masih belum bisa dikatakan ideal, karena memang masih banyak hambatan yang dihadapi. Lembaga pendidikan yang seharusnya dapat menjadi sarana untuk anak agar bisa mengembangkan bakat serta minatnya, namun kini hal tersebut sulit untuk terealisasikan. Agar dapat mewujudkan hal tersebut sangatlah diperlukan kesiapan antara pendidik, kurikulum pendidikan, ketersediaan sumber ajaran, serta dukungan fasilitas digital dan jaringan yang memadai agar terciptanya komunikasi yang baik dan efisien antara tenaga pendidik dan peserta didik. 
Sejak 16 maret 2020, 213 pengaduan baik dari orang tua maupun anak telah diterima oleh Komisi Perlindungan Anak Indonesia (KPAI) terkait dengan PJJ (Basar, 2021). Seperti halnya yang terjadi di Kampung Cikaso, berikut adalah keluhan dari salah satu siswa yang baru beranjak dari SD ke jenjang pendidikan SMP.

"Sekolah online mah bikin pusing, yang ada malah terus-terusan dikasih tugas, padahal gak ngerti. Kadang mah nggak dikerjain, karena hampir semua anak cowo di kelas juga gak ada yang ngerjain apalagi kalau gak ada kuota dan sinyalnya lemot. Terus sama gurunya juga gak dihukum apa-apa" (Maulana, 2021).

Sejauh ini, dapat kita simpulkan bahwa sistem pembelajaran daring memanglah belum bisa dikatakan ideal untuk dijadikan solusi dalam pembelajaran. Terlebih untuk masyarakat di pedesaan, banyak sekali hambatan yang mereka hadapi. Mulai dari tenaga pendidik dan peserta didik yang kurang siap dengan sistem pembelajaran yang serba online, kurangnya edukasi tentang media digital, dan sistem kurikulum yang belum sepenuhnya sempurna (Basar, 2021).

\section{Analisis Moralitas Anak Masa Pandemi Perspektif Immanuel Kant}

Sebagaimana yang telah diulas sebelumnya, bahwa gagasan Immanuel Kant mengenai etika adalah deontologi. Yang mana secara bahasa berasal dari kata deon yang berarti keharusan, kewajiban, atau sesuatu yang diwajibkan, dan logos yang berarti ilmu. Secara ringkas bisa dikatakan bahwa deontologi adalah suatu ilmu yang membahas tentang kewajiban manusia untuk berbuat baik dan menghindari perbuatan buruk. Deontologi berkaitan dengan sikap moral seseorang yang bersangkutan pula dengan tututan kewajiban dan perintah moral dalam hubungan sosial masyarakat. Jika melihat temuan akan fakta yang terjadi di Kampung Cikaso, maka problematika moralitas anak yang terjadi pada masa pandemi Covid-19 perspektif Immanuel Kant adalah sebagai berikut:

\section{a) Sistem Moralitas Immanuel Kant}

Selain membahas mengenai pentingnya pendidikan, Immanuel Kant juga mengemukakan adanya tahapan-tahapan dalam pendidikan. Menurut Kant, sejarah umat manusia merupakan proses dari keadaan hewani menuju ke arah manusiawi, dari pengguna insting menuju pengguna rasio (akal budi), dari mengikuti hukum alam menuju kebebasan, dari keadaan kurang baik menuju keadaan lebih baik bahkan nyaris sempurna. Namun sekali lagi, Kant menyadari bahwa perkembangan moral manusia selalu mengalami proses perubahan tahap demi tahap sehingga tidak menutup 
kemungkinan akan mengalami perubahan di setiap tahunnya (Kuntjoro, 2016).

Kant merupakan filsuf asal Jerman (1724-1804), ia berasal dari keluarga protestan yang shaleh, yang keshalehannya telah dapat mempengaruhi pemikiran moralitasnya. Dalam bukunya yang berjudul "Simpul Pemikiran Etika Immanuel Kant Implementasinya dalam Pembelajaran" Kant mengemukakan bahwa dalil pertama moralitas adalah memiliki nilai moral sejati, dan perbuatan harus dikerjakan sesuai kewajiban (Widyawati s. , 20016).

Moralitas Kant, berasaskan pada kewajiban dan imperatif kategoris. Yang mana hal tersebut sangatlah mengedepankan rasio yang murni, sehingga moralitas menjadi otoritas tertinggi dalam diri. Nilai moral yang baik akan mendukung pada suatu tindakan yang sesuai dengan kewajiban. Hal tersebut sesuai dengan apa yang disampaikan oleh Ustadz Dede Abdu Fatah selaku guru ngaji di Kampung Cikaso:

"Sopan santun anak itu tergantung pada karakter anak itu sendiri. Ketika anak bertemu dengan seseorang yang merupakan gurunya, maka ia akan hormat. Namun lain halnya ketika ia bertemu dengan orang biasa saja, walaupun derajatnya lebih tinggi atau lebih dewasa, terkadang anak itu tidak bisa menghargai atau menghormatinya. Karena memang di masa pandemi ini, pendidikan karakter itu tidak dicontohkan, anak seperti kehilangan sosok yang bisa digugu dan ditiru yang tiada lain adalah seorang guru" (Fatah, 2021).

Melihat fenomena tersebut, maka sangatlah penting bagi kita untuk dapat memahami dan mengamalkan konsep etika atau moralnya Immanuel Kant. Karena pada dasarnya, ajaran deontologi Immanuel Kant sangatlah mengedepankan kewajiban universal. Sehingga setiap orang harus berlaku baik dan memandang manusia seutuhnya tanpa memandang bulu, dan harus berdasarkan pada kewajiban itu sendiri (Effendi, 2020). Ketika kita menghormati seseorang, hormatilah dia sebagai mana mestinya, janganlah pilih-pilih apalagi sampai membeda-bedakan status sosialnya.

Adanya sistem kewajiban moral yang dinisbatkan kepada Immanuel Kant karena ia yang mempelopori adanya kewajiban moral yang ada pada setiap diri manusia. Kewajiban tersebut dilaksanakan tanpa adanya dorongan, tekanan, atau paksaan dari berbagai arah. Dengan begitu, kewajiban tersebut dilaksanakan atas dasar kesadaran dan kehendak pada diri sendiri. Jika terbukti adanya dorongan atau paksaan dari pihak luar, maka hal tersebut tidak bisa dikatakan sebagai kewajiban. 


\section{b) Pembagian Moralitas Immanuel Kant}

Kewajiban yang menjadi asas dalam konsep etika Immanuel Kant adalah kewajiban manusia yang menjadi adikodrati dalam diri setiap manusia. Suatu perbuatan tidak bisa dinilai baik atau buruk jika hanya dipandang dari sebab akibat yang akan ditimbulkan. Seseorang yang berlaku baik, menolong sesama, memberi makan, dan menyingkirkan paku di jalanan adalah merupakan suatu tindakan kebaikan. Karena tindakan tersebut memberikan dampak terhadap orang lain secara jelas. Namun dalam sudut pandang lain, membangkang perkataan orang tua, mencuri barang orang lain, membuang sampah sembarangan hingga korupsi besarbesaran, adalah suatu tindakan yang dapat memberikan dampak buruk juga terhadap orang lain bahkan untuk negara (Effendi, 2020).

Bagi Kant, segala hal yang timbul akibat dari suatu tindakan yang dilakukan tidak berdasarkan pada etika sebenarnya. Karena masih memandang perlu adanya akibat yang ditimbulkan dari perbuatan tersebut. Kewajiban harus menjadi sesuatu yang meniscaya, sehingga dasar manusia untuk bertindak adalah kewajiban yang mana kewajiban itu harus sesuai dengan rasio praktis manusia. Kewajiban dari rasio praktis akan melahirkan tindakan untuk melakukan tindakan baik, dan meninggalkan perbuatan buruk. Dengan demikian, pengetahuan moral bukan berdasarkan pada segala sesuatu yang ada (das sein) melainkan dari yang seharusnya ada (das sollen). Oleh karena itu, keharusan dalam bertindak akan mencerminkan pada kehendak baik seseorang tanpa adanya motif atau dorongan yang ada dalam dirinya (Effendi, 2020).

Tindakan etis yang dilakukan oleh manusia akan menunjukan sikap terhadap perilaku yang dimilikinya. Karena etika merupakan sesuatu yang inhern yaitu tinggal dalam dirinya, yang melekat baik secara spontanitas maupun verbal.

Immanuel Kant membagi dua perintah berbuat baik ke dalam dua bagian, yang pertama yaitu perintah bersyarat (imperatifhipotesis) dan yang kedua adalah perintah tak bersyarat (imperatifkategoris) (Diamastuti , 2019), sedangkan penjelasannya akan diulas sebagai berikut:

\section{1) Imperatif Hipotesis}

Imperatif hipotesis adalah cara pandang terhadap suatu perbuatan yang dilakukan sebagai alat untuk mencapai sesuatu. Hal tersebut dilakukan karena adanya tujuan yang ingin dicapai dalam suatu kewajiban (Effendi, 2020). Seperti halnya yang dijelaskan oleh Rosita berikut:

"Anak saya itu akan rajin ketika memang ada maunya. Dia mau mengantar jemput saya ke pasar, asalkan pulangnya dikasih uang jajan" (Rosita, 2021). 


\section{2) Imperatif Kategoris}

Imperatif kategoris adalah cara pandang terhadap suatu perintah kewajiban sebagai suatu yang tiada syarat, tidak ada tujuan yang ingin dicapai dan tak mempertanyakan kembali atas perintah tersebut. Imperatif kategoris inilah yang dijadikan dasar etika Immanuel Kant. Begitupun dengan penuturan yang disampaikan oleh Ustadz Dede Abdul Fatah terhadap sikap atau perilaku yang dimiliki oleh para santri untuk mengikuti kegiatan pengajian, berikut adalah penjelasannya:

“Dalam masa pandemi ini, pengajian sama sekali tidak diliburkan. Namun dalam pelaksanaannya, banyak sekali santri yang tidak ikut mengaji. Terlebih ketika bulan Ramadhan tiba dan diadakannya pesantren kilat. Hampir setengahnya para santri tidak mengikuti kegitan tersebut dan bahkan hanya beberapa orang saja yang hadir. Mereka yang hadir pun hanya santri-santri yang sadar akan kewajibannya karena sama sekali tidak ada hukuman bagi santri yang tidak ikut mengaji. Begitu pun dengan dukungan yang diberikan oleh orang tua sangatlah minim, berbeda dengan kegiatan pada bulan-bulan Ramadhan sebelumnya. Jadi seakan-akan yang hadirpun memang benar-benar santri yang semangat belajarnya masih tinggi" (Dede Abdul Fatah, 2021).

Melihat fenomena tersebut, dapat kita pahami bahwa anak yang sadar akan kewajibannya untuk mencari ilmu itu hanya beberapa orang saja. Dan kebanyakan dari mereka, akan menjalankan kewaibannya jika memang ada penekanan atau dorongan dari pihak lain terebih dahulu.

Dari seluruh uraian di atas, dapat disimpulkan bahwa teori Deontologi Immanuel Kant menjelaskan bahwa dalil pertama moralitas adalah memiliki nilai moral sejati, dan perbuatan harus dikerjakan sesuai kewajiban. Kewajiban tersebut dilaksanakan tanpa adanya dorongan, tekanan, atau paksaan dari berbagai arah. Dengan begitu, kewajiban dilaksanakan atas dasar kesadaran dan kehendak pada diri sendiri. Jika terbukti adanya dorongan atau paksaan dari pihak luar, maka hal tersebut tidak bisa dikatakan sebagai kewajiban. Oleh karena itu, dapat kita pahami bahwa moralitas anak yang ada di Kampung Cikaso itu termasuk pada imperatif hipotesis, karena untuk melaksanakan kewajibannya anak memerlukan dorongan dan tekanan dari pihak lain terlebih dahulu. Sedangkan Immanuel Kant lebih menekankan agar kita memiliki nilai moral yang bersifat imperatif kategoris, yang mana dalam pelaksanaan kewaijbannya itu atas dasar kesadaran diri sendiri dan bukan karena adanya tekanan atau dorongan dari pihak lain. 


\section{Kesimpulan}

Berdasarkan temuan akan fakta yang ada di masyarakat Kampung Cikaso, maka dihasilkan beberapa kesimpulan yakni, problematika moralitas anak pada masa pandemi ini memanglah sangat kurang diperhatikan oleh pihak pemegang kebijakan. Pembelajaran jarak jauh (daring) belum bisa dikatakan ideal untuk dijadikan solusi dalam pembelajaran. Di sini, teori dari Immanuel Kant dijadikan sebagai pisau analisis terhadap sikap moral yang dimiliki oleh anak-anak di Kampung Cikaso. Kant lebih menekankan agar mereka dapat memiliki nilai moral yang bersifat imperatif kategoris, karena dengan begitu mereka bisa melaksanakan kewajiban tanpa adanya paksaan atau dorongan dari pihak lain dan itulah yang dijadikan landasan dalam filsafat etika Kant untuk mendapatkan nilai moral sejati. Penelitian ini diharapkan bermanfaat bagi pembaca dan menambah khazanah keilmuan khususnya dalam bidang filsafat etika dan moral, juga supaya dapat memberikan perspektif baru di kalangan masyarakat. Penelitian ini pun memiliki keterbatasan literatur, sehingga dibutuhkan penelitian lebih lanjut dengan literatur yang lebih lengkap. Oleh karena itu, penulis berharap agar kajian ini dapat menjadi pembuka untuk memulai kajian-kajian berikutnya.

\section{Daftar Pustaka}

Alifah, M., Adha, M. M., Perdana, D. R., Hartino, A. T., \& Rifai, A. (2021). Upaya Meningkatkan Karakter disiplin Peserta Didik pada Pembelajaran daring di Masa Pandemi Covid-19.

Asdi, E. D. (1995). Imperatif kategoris dalam filsafat moral Immanuel Kant. Jurnal Filsafat, 1(1), 9-19.

Asmuni, A. (2020). Problematika Pembelajaran Daring di Masa Pandemi Covid-19 dan Solusi Pemecahannya. Jurnal Paedagogy, 7(4), 281-288. Azwar, S. (1999). Metode Penelitian. Jakarta: Pustaka Pelajar.

Basar, A. M. (2021). Problematika Pembelajaran Jarak Jauh Pada Masa Pandemi Covid-19:(Studi Kasus di SMPIT Nurul Fajri-Cikarang Barat-Bekasi). Edunesia: Jurnal Ilmiah Pendidikan, 2(1), 208-218.

Desa Sukamukti . (2019). Profil Desa Sukamukti. Garut: Arsip Desa Sukamukti .

Dewi, W. A. F. (2020). Dampak Covid-19 terhadap implementasi pembelajaran daring di Sekolah Dasar. Edukatif: Jurnal Ilmu Pendidikan, 2(1), 55-61.

Diamastuti , E. (2019, januari 5). Deontologi Dalam Praktek Etika. Retrieved juni sabtu, 2021, from researchgate: https:/ / www.researchgate.net/profile/Erlina_Diamastuti/publicatio n/330655329_Deontologi_Dalam_Praktik_Etika_Simposium_Nasiona 1_Akuntansi_XX/links/5c4c7bc8299bf12be3e5762c/DeontologiDalam-Praktik-Etika-Simposium-Nasional-Akuntansi-XX.pdf 
Effendi, R. (2020). Kewajiban dalam Pemikiran Immanuel Kant dan Relevansinya dengan Akhlak Islam. JURNAL AL-AQIDAH, 12(2), 5367.

Fatah, D. A. (2021, Mei 29). Faktor Yang Mempengaruhi Moralitas Anak. (Y. Wahyuni , Interviewer)

Kuntjoro, A. P. (2016). Pendidikan Moral sebagai Metode dalam Proyek Etika Immanuel Kant. Respons: Jurnal Etika Sosial, 21(02).

Maulana, S. (2021, april 22). Problematika Moralitas Anak Di Kampung Cikaso. (Y. Wahyuni, Interviewer)

Oamidin. (2020, Desember 20). Dampak Negatif Pembelajaran Jarak Jauh. (Y. Wahyuni , Interviewer)

Pasaribu, N. L. (2018). Analisis Pengaru Linghkungan, Tingkat Pendidikan Dan Pendapatan Orang Tua Terhadap Moralitas Anak . Repositori Institusi Universitas Sumatra Utara, http://repositori.usu.ac.id/handle/123456789/7010.

Purnama, A. Y., \& Rani, S. A. (2021). Solusi Bias Kognitif, Kesenjangan Digital dan Moralitas di Era Pandemi Covid-19. Indonesian Journal Of Education and Humanity, 1(1), 63-68.

Permatasari, M. R. (2020). Work From Home (WFH) dan Pembentukan Kecerdasan Moral Anak di Era Pandemi Covid 19. Wahana Islamika: Jurnal Studi Keislaman, 6(2), 163-179.

Rosita. (2021, April 20). Faktor Yang Mempengaruhi Moralitas Anak. (Y. Wahyuni, Interviewer)

Saepul. (2020, Desember 20). Dampak Negatif Pembelajaran Jarak Jauh. (Y. Wahyuni, Interviewer)

Sugiyono. (2014). Metode Penelitian Kuantitatif dan Kualitatif. Bandung: Alfabeta.

Susilo, A., Rumende, C. M., Pitoyo, C. W., Santoso, W. D., Yulianti, M., Herikurniawan, H., ... \& Yunihastuti, E. (2020). Coronavirus disease 2019: Tinjauan literatur terkini. Jurnal Penyakit Dalam Indonesia, 7(1), 45-67.

Tanzeh, A. (2011). Metodologi Penelitian Praktis. Yogyakarta: Teras.

Utami, D. T. (2018). Pengaruh Lingkungan Teman Sebaya Terhadap Perilaku Sosial Anak Usia 5-6 Tahun. Generasi Emas: Jurnal Pendidikan Islam Anak Usia Dini, 1(1), 39-50.

Widyawati, S. (2016). Simpul Pemikiran Etika Imanuel Kant Implementasinya Dalam Pembelajaran. Surakarta: Isi Pres. 